\title{
Toxoplasmosis retinochoroiditis after photodynamic therapy and intravitreal triamcinolone for a supposed choroidal neovascularization: a case report
}

\author{
Retinocoroidite toxoplá smica após terapia fotodinâ mica e triancinolona intravítrea em \\ suposta neovascularização de coróide: relatode um caso
}

\author{
Mário Junqueira Nóbrega ${ }^{1}$ \\ Evandro Luís Rosa²
}

\begin{tabular}{l} 
ABSTRACT \\
\hline The purpose is to report a complication after photodynamic therapy (PDT) \\
and intravitreal triamcinolone for a presumed choroidal neovascularization \\
in age-related macular degeneration. Photodynamic therapy and intravitreal \\
triamcinolone were used in an 84-year-old man with choroidal neovascu- \\
larization in the left eye. Forty-five days after therapy, the patient returned \\
with severe necrotizing uveitis in the posterior pole and vitritis. Laboratory \\
investigation disclosed a high anti-Toxoplasma IgG titer. Therapy with \\
pyrimethamine, sulfadiazine and folinic acid resulted in total lesion healing \\
although central vision was lost. Intravitreal triamcinolone may have had \\
an influence on the exacerbation of retinochoroiditis in the posterior pole \\
of the patient. Although rare, this complication may not be disregarded in \\
the cases that require intraocular corticosteroids for treatment of several \\
conditions, especially in patients who had previously suffered from \\
toxoplasmosis infection.
\end{tabular}

Keywords: Uveitis; Toxoplasmosis, ocular; Triamcinolone/adverse effects; Choroidal neovascularization; Vitreous body; Injections; Case reports [publication type]

\section{INTRODUCTION}

Photodynamic therapy (PDT) is one of the most important recent advances for treatment of choroidal neovascularization (CNV) associated with many diseases, especially age-related macular degeneration (AMD) ${ }^{(1-2)}$. Lately, the association of PDT and intravitreal injection of triamcinolone acetonide has shown potential short-term benefit in the management of CNV secondary to $\mathrm{AMD}^{(3-5)}$. Although effective in the treatment of some diseases of the posterior segment, intraocular triamcinolone can cause side effects, especially ocular hypertension, cataract and pseudohypopyon ${ }^{(6-9)}$.

We describe a severe complication after photodynamic therapy (PDT) and intravitreal triamcinolone for a presumed choroidal neovascularization in age-related macular degeneration.

\section{CASE REPORT}

A 84-year-old white male, from Luís Alves (SC), was referred with a 7day complaint of decreased central vision in the left eye. His best-corrected visual acuity was 20/30 in the right eye and 20/70 in the left eye. Slit lamp biomicroscopy showed a mild nuclear cataract in both eyes. Intraocular 
158 Toxoplasmosis retinochoroiditis after photodynamic therapy and intravitreal triamcinolone for a supposed choroidal neovascularization: a case report

pressure was $14 \mathrm{mmHg}$ and $13 \mathrm{mmHg}$, respectively. Eye fundus examination disclosed no abnormalities in the right eye; in the left eye, there was a juxtafoveal yellow-white lesion of less than one disc area and poorly defined margins; there were also a slight sensory retinal detachment around the lesion and a small atrophic area inferior to it. Fluorescein angiography showed an early hyperfluorescence of the juxtafoveal lesion with intense leakage and late pooling of fluorescein under the detached retina (Figure 1).

A diagnosis of choroidal neovascularization secondary to age-related macular degeneration was established. The patient was submitted to PDT using verteporfin. An adjuvant intravitreal injection of $4 \mathrm{mg}$ triamcinolone acetonide was performed 4-days after PDT. Forty-five days after the injection, the patient returned with a 15-day history of intense visual deficit in the treated eye. His best-corrected visual acuity was $20 / 30$ in the right eye and counting fingers at 2 meters in the left eye. Slit lamp biomicroscopy showed mild nuclear cataract in both eyes and vitreal cells $2+$ in the left eye. Intraocular pressure was $15 \mathrm{mmHg}$ and $12 \mathrm{mmHg}$, respectively. Fundoscopy was unremarkable in the right eye; in the left eye, there was a moderate vitritis associated with a severe retinochoroiditis affecting the whole macula and a pale optic disc (Figure 2). Laboratory investigation disclosed an IgG anti-Toxoplasma titer of $250 \mathrm{IU}$. The patient was treated with pyrimethamine, sulfadiazine and folinic acid and, after three weeks, the vitreous was clearer and there was almost complete lesion healing. As the patient could not continue taking the medication due to gastric intolerance, sulfamethoxazole and trimethoprim were given daily for other four weeks, followed by 3 times a

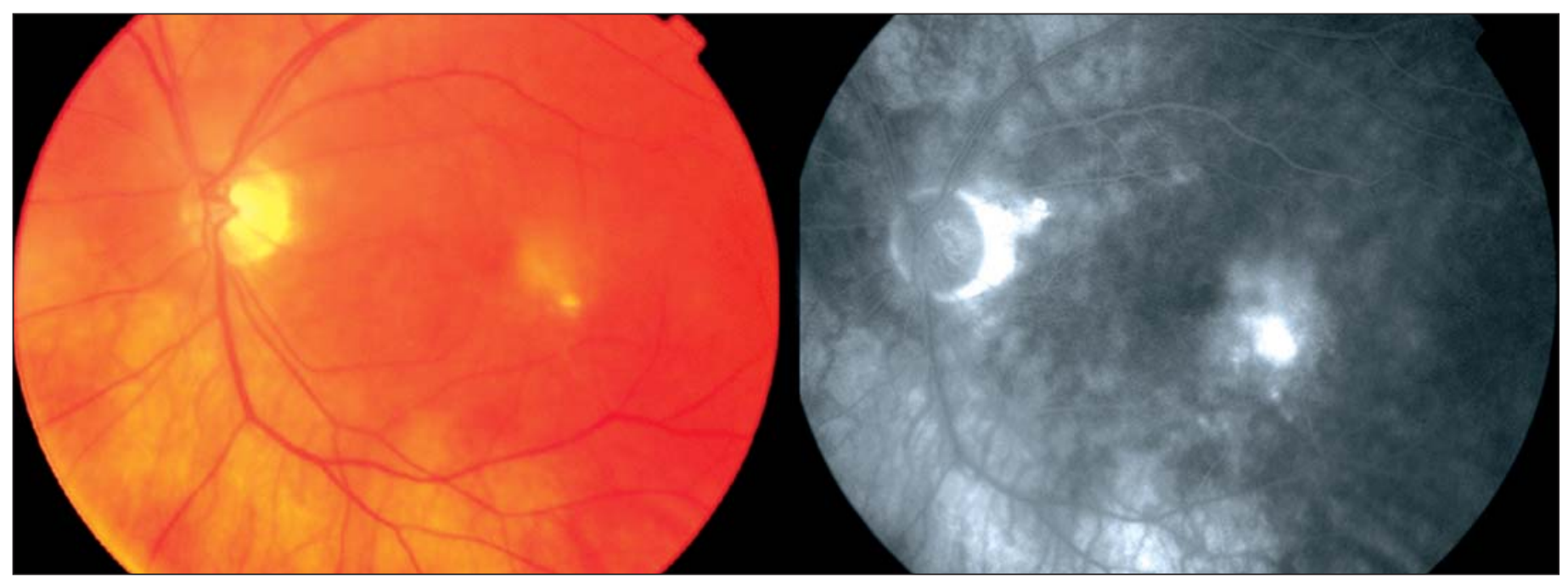

Figure 1 - Left fundus of the patient prior to the treatment. Left: there is a yellow-white juxtafoveal lesion with adjacent sensory retinal detachment and a small atrophic area inferior to it. Right: late fluorescein angiogram reveals intense leakage of the lesion and pooling in the detached area.

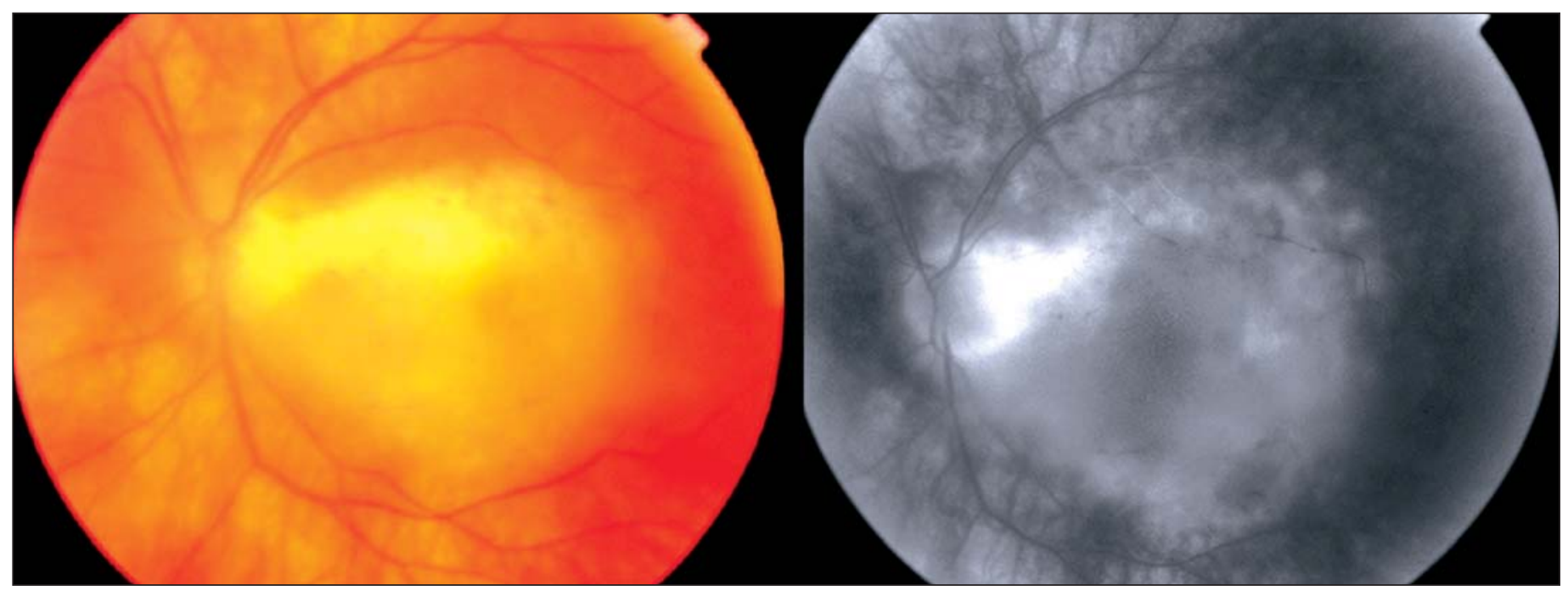

Figure 2 - Same eye 45 days after PDT and intravitreal triamcinolone. Left: there is a moderate vitritis associated with a severe macular active retinochoroiditis and a pale optic disc. Right: late phase angiogram shows diffuse leakage in the macula. 
week continuously. There were no relapses till the last examination, performed 14 months after starting toxoplasmosis therapy. Final best-corrected visual acuity was 20/30 in the right eye and counting fingers at 2 meters in the left eye.

\section{DISCUSSION}

Age-related macular degeneration (AMD) is a very common cause of legal blindness in the United States among people 40 years of age and older ${ }^{(10)}$. In Brazil, this disease is also frequent and it can provoke a bilateral visual impairment among older people $^{(11)}$.

Although neovascular or exudative AMD is far less common than nonneovascular or nonexudative AMD, it usually causes a more severe visual loss. The management of neovascular AMD is still controversial and includes laser photocoagulation, submacular surgery, PDT and pharmacologic intervention ${ }^{(12)}$.

Nowadays, PDT is considered one of the most useful therapies for exudative AMD because it promotes a selective destruction of CNV with preservation of the overlying neurosensory retina ${ }^{(1-2)}$.

Recently, combined PDT and intravitreal triamcinolone acetonide have been used for CNV secondary to AMD, with promising results, particularly when applied as first-line therapy ${ }^{(3-5)}$.

Demographics, medical history, ophthalmologic examination and fluorescein angiography were suggestive that the cause of visual loss in the left eye of the patient was CNV due to AMD. And this is the reason that combined PDT and intravitreal triamcinolone were used.

Otherwise, the possibility of misdiagnosis of choroidal neovascularization must not be excluded. The supposed subretinal neovascular membrane could be, in fact, an active toxoplasmosis satellite lesion adjacent to a previous small atrophic scar (Figure 1).

A highly positive IgG anti-Toxoplasma titer and a good response to specific therapy show that toxoplasmosis was probably involved in the pathogenesis of this devastating manifestation.

In addition, it is known that corticosteroids must not be used without simultaneous antimicrobial cover for treatment of ocular toxoplasmosis and periocular injections are contraindicated to avoid local immunosuppression and uncontrollable disease ${ }^{(13)}$.

Although unusual, the related complication may not be neglected in patients that require intraocular corticosteroids for treatment of several conditions, especially in patients with previous ocular toxoplasmosis findings.

\section{CONCLUSION}

Intravitreal triamcinolone may have had an influence on the exacerbation of retinochoroiditis in the posterior pole of the patient. This complication may not be disregarded in the cases that need intraocular corticosteroids for treatment of several diseases, especially in patients who had previously suffered from toxoplasmosis infection.

\section{RESUMO}

O objetivo é relatar complicação após terapia fotodinâmica (PDT) e triancinolona intravítrea para presumida neovascularização de coróide em degeneração macular relacionada à idade. A terapia fotodinâmica e triancinolona intravítrea foram utilizados em paciente de 84 anos, do sexo masculino, com neovascularização de coróide no olho esquerdo. Quarenta e cinco dias após o tratamento, o paciente retornou com grave retinite necrosante do pólo posterior e vitreíte. Investigação laboratorial indicou alto título de IgG anti-Toxoplasma. Tratamento com pirimetamina, sulfadiazina e ácido folínico levaram à total cicatrização da lesão embora a visão central tenha sido comprometida. Conclui-se que a triancinolona intravítrea pode ter influenciado na exacerbação da retinocoroidite no pólo posterior do paciente. Embora rara, esta complicação não pode ser descartada nos casos que necessitem corticóide intra-ocular para tratamento de várias doenças, principalmente em pacientes que tenham tido surtos prévios de toxoplasmose ocular.

Descritores: Uveíte; Toxoplasmose ocular; Triancinolona/ efeitos adversos; Neovascularização coroidal/terapia; Corpo vítreo; Injeções; Relatos de casos [tipo de publicação]

\section{REFERENCES}

1. Bressler NM. Treatment of Age-Related Macular Degeneration with Photodynamic Therapy (TAP) Study Group. Photodynamic therapy of subfoveal choroidal neovascularization in age-related macular degeneration with verteporfin: two-year results of 2 randomized clinical trials-tap report 2. Arch Ophthalmol. 2001;119 (2):198-207. Comment in: Arch Ophthalmol. 2005;123(9):1283-5.

2. Verteporfin in Photodynamic Therapy Study Group. Verteporfin therapy of subfoveal choroidal neovascularization in age-related macular degeneration: two-year results of a randomized clinical trial including lesions with occult with no classic choroidal neovascularization-verteporfin in photodynamic therapy report 2. Am J Ophthalmol. 2001;131(5):541-60. Comment in: Am J Ophthalmol. 2002;133(2):294-6. Am J Ophthalmol. 2002;133(1):168-9. Am J Ophthalmol. 2002;133(6):857; author reply 857-9.

3. Spaide RF, Sorenson J, Maranan L. Combined photodynamic therapy with verteporfin and intravitreal triamcinolone acetonide for choroidal neovascularization. Ophthalmology. 2003;110(8):1517-25.

4. Rechtman E, Danis RP, Pratt LM, Harris A. Intravitreal triamcinolone with photodynamic therapy for subfoveal choroidal neovascularisation in age related macular degeneration. Br J Ophthalmol. 2004;88(3):344-7.

5. Spaide RF, Sorenson J, Maranan L. Photodynamic therapy with verteporfin combined with intravitreal injection of triamcinolone acetonide for choroidal neovascularization. Ophthalmology. 2005;112(2):301-4.

6. Jonas JB, Kreissig I, Kamppeter B, Degenring RF. [Intravitreal triamcinolone acetonide for the treatment of intraocular edematous and neovascular diseases] Ophthalmologe. 2004 Feb;101(2):113-20. German.

7. Andrade REA, Muccioli C, Farah ME. Injeção intravítrea de triancinolona no tratamento da síndrome de Vogt-Koyanagi-Harada. Arq Bras Oftalmol. 2004; 67(3):401-6.

8. Campos VE, Maia A, Muccioli C, Belfort R Jr. Pseudohypopyon immediately after intravitreal injection of triamcinolone acetonide - case reports. Arq Bras Oftalmol. 2005;68(2):251-2.

9. Jonas JB, Kreissig I, Degenring R. Intraocular pressure after intravitreal injection of triamcinolone acetonide. Br J Ophthalmol. 2003;87(1):24-7. Comment in: Br J Ophthalmol. 2004;88(4):598; author reply 598. 
10. Friedman DS, O'Colmain BJ, Muñoz B, Tomany SC, McCarty C, de Jong PT, et al. Prevalence of age-related macular degeneration in the United States. Arch Ophthalmol. 2004;122(4):564-72. Comment in: JAMA. 2004;291(15):1900-1.

11. Santos LPF, Diniz JR, Leão ACS, Sena MF. Degeneração macular relacionada à idade: prevalência e fatores de risco em dois centros oftalmológicos de referência em Pernambuco. Arq Bras Oftalmol. 2005;68(2):229-33.
12. Loewenstein A, Bressler NM. Neovascular (exudative) age-related macular degeneration. In: Guyer DR, Yannuzzi LA, Chang S, Shields JA, Green WR. editors. Retina-vitreous-macula. Philadelphia: W. B. Saunders; 1999. p.94-121.

13. Da Mata AP, Oréfice F. Toxoplasmosis. In: Foster CS, Vitale AT, editors. Diagnosis and treatment of uveitis. Philadelphia: W. B. Saunders; 2002. p.385-410.

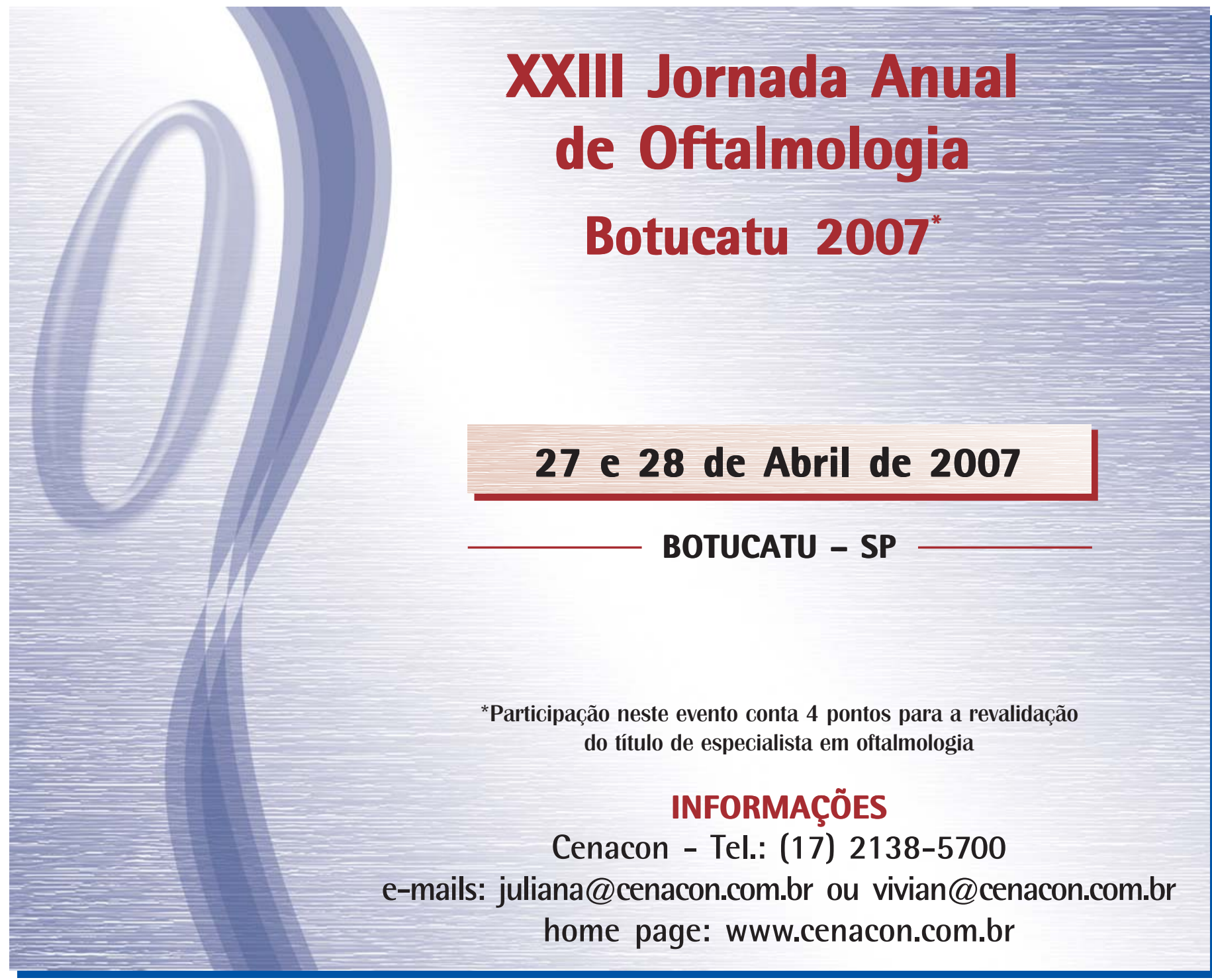

